\title{
GLOBALIZATION CRISES, TRADE AND DEVELOPMENT IN VIETNAM
}

\author{
PHILIP ABBOTT** and FINN TARP ${ }^{\dagger, t}$ \\ *Department of Agricultural Economics \\ Purdue University, Krannert Bldg, 403 W State Street \\ West Lafayette, IN 47907-2056, USA \\ 'Department of Economics \\ Copenhagen University \\ Copenhagen, Denmark \\ Director of the UNU World Institute for Development \\ Economics Research (UNU-WIDER) \\ Helsinki, Finland
}

\begin{abstract}
Vietnam has been among the most successful East Asian economies, especially in weathering the external shocks of recent globalization crises. Examination of economic performance and policy responses shows rising dependence on foreign finance around each crisis, and actions by the government to counteract that dependence and bolster the domestic economy while continuing to restructure the economy toward greater emphasis on the private sector. Growth, employment and poverty alleviation have been maintained at the expense of renewed inflation, larger budget deficits, and currency depreciation. The "stop-go" nature of present macroeconomic policy is the consequence of balancing growth versus inflation, responding to severe external shocks and holding to a growth objective in the face of substantial internal and external criticism.
\end{abstract}

Keywords: Trade and development; trade liberalization; foreign direct investment; globalization; WTO accession; Asian financial crisis; great recession; Vietnam.

JEL Classification: F13, F14, O24, O53

\section{Introduction}

Vietnam has been among the most successful East Asian economies since "Doi Moi" reforms began in 1986. Economic growth surpassed 9 percent per year just prior to the Asian financial crisis in 1997-1998, and exceeded 8 percent per year before the great recession and financial crisis in 2008-2009. Vietnam weathered those crises better than most of its neighbors. Gross Domestic Product (GDP) growth slowed less and quickly recovered to rates near those experienced before those crises. Figure 1 compares GDP

This is an Open Access article published by World Scientific Publishing Company. It is distributed under the terms of the Creative Commons Attribution 4.0 (CC BY-NC) License. Further distribution of this work is permitted, provided the original work is properly cited and is not used for commercial purposes. 


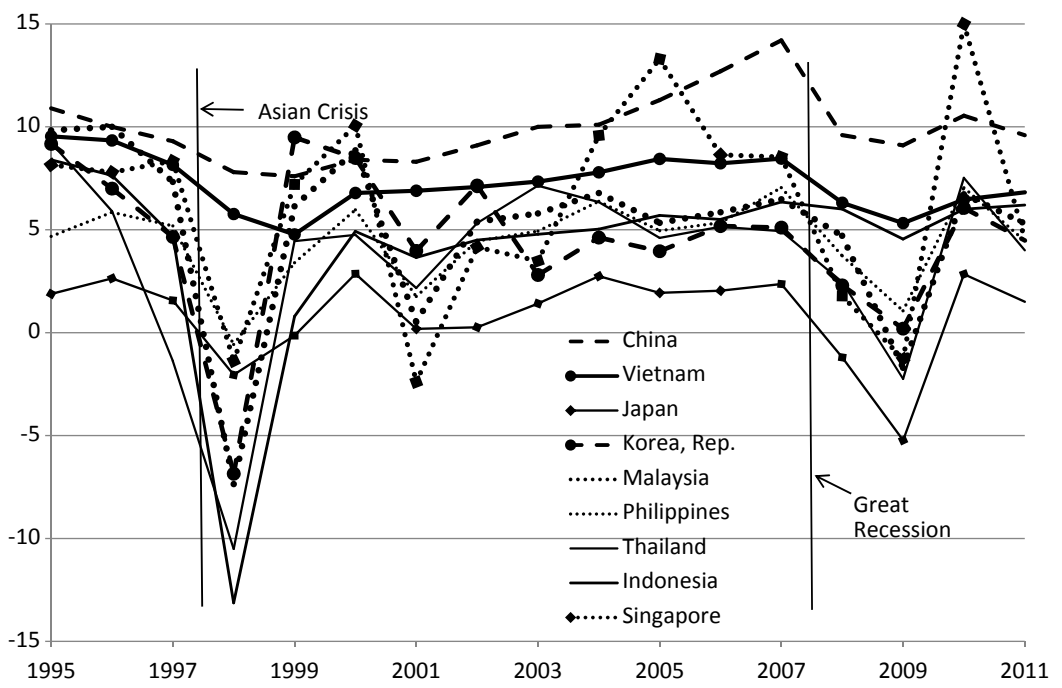

Figure 1. GDP growth rates (percent/year) in selected East Asian countries, 1995-2011 Source: World Bank (2011) and IMF (2010b) for projections beyond 2008.

growth rates for selected East Asian countries from 1995 until 2008 (World Bank, 2011), with the International Monetary Fund (IMF)'s recent estimates and forecasts of expected growth to 2011 (IMF, 2010b) included to illustrate the robust recovery expected in this region. It shows Vietnam's growth rate was on average above most other countries, except China, but with somewhat less catch-up growth following each of the two "globalization crises." As the latter crisis unfolded, expectations on Vietnamese economic growth were continually revised upward, as well. In April 2009, the IMF expected Vietnam to grow at only 3.3 percent for 2009 and 4 percent for 2010, but actual growth rose to 5.3 percent in 2009 and is expected to reach 6.5 percent in 2010 (IMF, 2010b).

Post-reform economic growth in Vietnam had been accompanied by trade liberalization reforms that then led to an explosion in international trade. Exports as a share of GDP grew from 26.4 percent in 1990 to 77.9 percent in 2008, while imports grew from 35.7 percent to 93.1 percent over that same period (IMF, 2011). This evidence led many to argue that Vietnam is an excellent example of "export led growth" (see Abbott et al., 2009). Yet, if that were the case, one would expect that Vietnam was especially vulnerable to the recent economic crisis. One key feature of the great recession and the financial crisis of 2008-2009 was an unprecedented collapse in global trade, especially short term trade in the last quarter of 2008 and the first quarter of 2009. According to short-term trade data assembled by the IMF (2010a), world exports declined over 60 percent at the valley of early 2009, and the World Trade Organisation (WTO) reports that for 2009 annual world export volume fell 12 percent while value fell 23 percent (WTO, 2010). Declines were more pronounced in developing countries, but were somewhat smaller for Asian countries at an 18 percent value decline. Moreover, Vietnam is a commodity exporter, as crude oil and rice are among its important exports. One factor contributing to the decline in trade was the end of 
a commodity boom in July 2008 brought about by the great recession and financial crisis. In Vietnam export value fell by 7.7 percent in 2009 from the peak level realised in 2008, but imports fell even more (11 percent). So the current account deficit declined (GSO, 2011) and trade contributed positively to economic growth as measured by final demand.

Vietnam has been buffeted by international events beyond the two recent "globalization crises" over the last two decades. Accession to the WTO in 2007 led to rapid expansion in both trade and inflows of foreign investments, and economic growth reached its recent peak at 8.5 percent in 2007 (GSO, 2011). A trade agreement with the European Union (EU) in 1992 spurred trade and growth, while numerous agreements after 2000, including a bilateral agreement with the United States (US) also accelerated trade and growth. In each case, foreign direct investment (FDI) into Vietnam surged for a time, as well, and it then declined as a result of each crisis. Abbott et al. (2010) argued that access by foreign investors was a more critical issue than tariff reductions and market access for trade in the WTO negotiations leading up to accession in 2007 (see Nga, 2007), and that subsequent impacts on the Vietnamese economy were driven as much or more by increased foreign investments than by increased trade. While trade may have declined in the recent crisis, longer term declines in foreign investment followed both crises.

Our prior analysis of Vietnamese trade and growth has emphasized the importance of investment in determining both trade and growth, and the importance of the state in determining both the level and allocation of investment (Abbott et al., 2008). Going into the recent crisis, Vietnam invested nearly 30 percent of GDP in 2000 and over 43 percent of GDP in 2007. The state, through its own capital expenditures or through state owned enterprises (SOEs), accounted for nearly 60 percent of that investment in 2000 and over 33 percent in 2007 in spite of rapid growth in both domestic private and foreign investment (GSO, 2011). Following each crisis the state share of investment rose briefly again. Our projections of sectoral trade levels followed closely sectoral investment allocations, influenced by both WTO concessions and state impact on investment patterns (Abbott et al., 2008). Riedel (2009), in his assessment of the impacts of the events in 2008 on the Vietnamese economy, also questioned the characterization of "export led growth" and noted that investments were needed to meet potential market access opportunities.

At least in Vietnam, the two strongest linkages to the global economy are trade and foreign investment. ${ }^{1}$ An important problem posed by the globalisation crises was increasing dependence on foreign investment, followed by declines in that source of financing during and after these crises. Each time the Vietnamese government actively intervened in both the macroeconomy and on investment to maintain economic growth rates. The emerging importance of private domestic investment was also

\footnotetext{
${ }^{1}$ Remittances are also important in Vietnam, but changes were not nearly as large as in FDI or trade. There may be some confusion in the data over what flows are remittances and what are investments from Vietnamese living overseas.
} 
addressed in stimulus to the economy (IMF, 2010a), and developments following each crisis reflect improving conditions in the domestic economy. While both trade and FDI were affected by external events, Vietnamese responses minimized impacts on the domestic economy, in particular growth, unemployment and poverty alleviation. The cost has been revived inflation, trade and government deficits, and recently a depreciating currency that troubles foreign investors who might be thinking about returning to Vietnam (Hookway, 2010; Bland, 2011).

This paper explores in more depth the changes in the Vietnamese economy before, during, and after the two recent "globalization crises." Our goals are: (i) to assess Vietnamese economic performance and policy responses during and after the two recent "globalization crises;" (ii) to highlight the importance of investment over trade in determining the evolution of the economy; (iii) to examine how tradeoffs between growth, financing and stabilization have been made, and (iv) to draw lessons for future macroeconomic policy.

The next section lays out a timeline of economic events and policy actions in Vietnam, putting the two crises in the perspective of longer term growth in GDP, trade and investment. The third section explores in more detail "real" outcomes and changes in trade, investment, growth, unemployment and poverty around these two crises. The fourth section examines fiscal and monetary policy responses. The fifth section considers the problem of financing the twin (government budget and trade) deficits, and the role of foreign finance in the savings-investment balance. The final concluding section contrasts our assessment of how well these crises were handled with those of Vietnamese critics, the Bretton Woods institutions, and foreign investors. We also consider the current macroeconomic debate as Vietnam strives to maintain economic recovery without overheating.

\section{Longer Term Perspective on Trade and Development}

Vietnam began transitioning to a more open, socialist-oriented market economy with the "Doi Moi" reforms of 1986. Its initial emphasis was on permitting privately-owned enterprises, but with continued state direction and involvement in the economy. Later policy actions reinforced greater interaction with and reliance on both trade and international finance, culminating in accession to the WTO in 2007. Table 1 lays out an abbreviated timeline of events that led to greater openness of the Vietnamese economy, and of international events that buffeted the economy along the way.

Trade policy adjustments lagged somewhat the 1986 "Doi Moi" reforms. It was only in 1989 serious attention to market oriented trade reforms began (Thanh, 2005). A unified exchange rate was adopted and state monopoly of foreign trade was eliminated. Trade began to take off following those reforms and subsequent to an agreement with the EU in 1992. In 1995, Vietnam joined the Association of South East Asian Nations (ASEAN) and began negotiations to join the WTO. It also joined the Asia Pacific Economic Cooperation (APEC) in 1998, and had completed over 57 bilateral trade agreements and 72 Most-Favored-Nation (MFN) agreements by 2000 
Table 1. Trade and development timeline since Doi Moi reforms in 1986

\begin{tabular}{cl}
\hline $\mathbf{1 9 8 6}$ & Doi Moi reforms begin \\
1989 & Market oriented trade reforms \\
& Unified exchange rate \\
& State monopoly of foreign trade eliminated \\
1992 & EU Trade Agreement \\
1995 & WTO Accession Working Party established \\
& Joined ASEAN \\
$\mathbf{1 9 9 7}$ & Asian Financial Crisis begins in December \\
1998 & Joined APEC \\
2002 & US-Vietnam Bilateral Trade Agreement implementation begins \\
$2004-2005$ & New laws on commerce and trade \\
2007 & WTO Accession \\
$\mathbf{2 0 0 8}$ & Commodity price boom ends in July \\
& Great recession and financial crisis \\
2009 & Global trade collapse \\
\hline
\end{tabular}

Sources: Vietnam specific events adapted from Abbott et al. (2009) and Thanh (2005).

(Niimi et al., 2007). An important bilateral agreement was reached with the US in 2000 and implemented in 2002, leading to the US moving from being a small trading partner to Vietnam's largest at the time of WTO accession. New agreements were reached at about that same time with the EU, China, and Japan. Vietnam subsequently reached accession agreements with 20 trading partners before entering the WTO in 2007 (Abbott et al., 2008). Actively negotiating trade agreements brought not only export opportunities, but also greater access by foreigners to the Vietnamese domestic economy via both imports and foreign investment.

This dramatic opening of the Vietnamese economy undoubtedly contributed to rapid GDP growth and explosion of trade from the early 1990s until 2008. Figure 2 shows the evolution of GDP and its final demand components over this period, highlighting both rapid growth and the increasing share of trade in GDP. ${ }^{2}$ Economic growth averaged 8.8 percent a year from 1992 until 1996, then stalled to 5.8 percent during the 1997-1998 Asian financial crisis, increasing again to 7.6 percent per year from 2000 to 2007 . Rapid growth was accompanied by extraordinary increases in trade (imports plus exports) as a share of GDP, from 23 percent in 1986 to 67 percent already in 1991, 97 percent in 1998 and 171 percent in 2007. Vietnam ran a trade deficit over this period, as imports have always exceeded exports. In 1992 exports equalled 34.7 percent of GDP while imports were 38.8 percent. In 2006 imports were 78.2 percent and exports 73.6 percent of GDP. When trade as a share of GDP peaked in 2008,

\footnotetext{
${ }^{2}$ Recent data on GDP and final demand components came from official Vietnamese statistics found on the website of the General Statistical Office (GSO, 2011). Older data consistent with official data were found from IMF (2011) and World Bank (2011) online datasets. Shares and growth rates were computed by the authors from these data.
} 


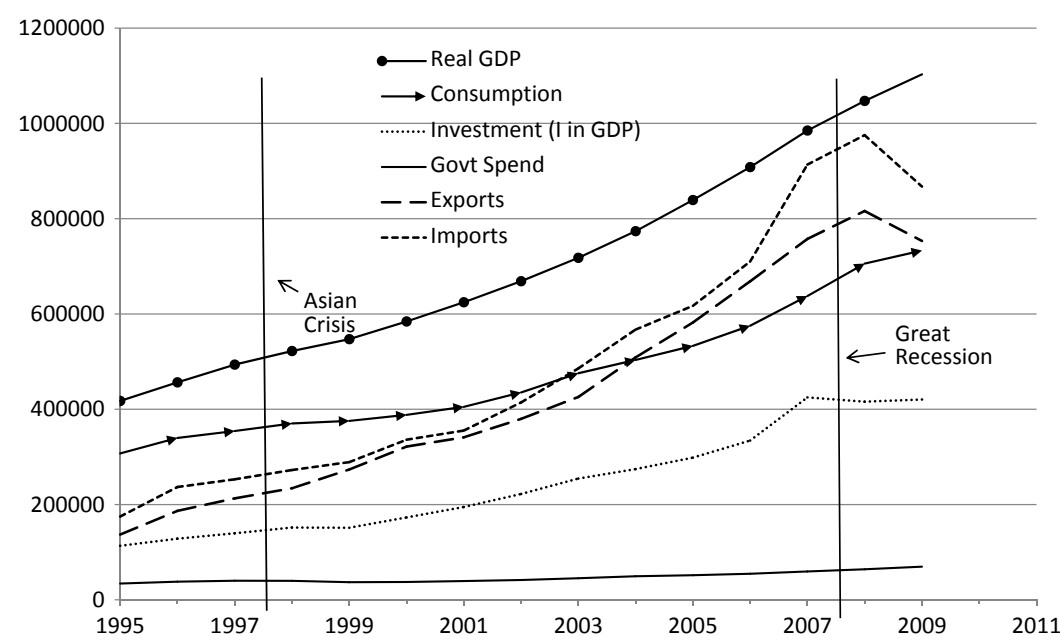

Figure 2. Real Vietnamese GDP and its components

Note: Units of measure are billion real (1994) Vietnamese dong.

Source: GSO online database (2011).

imports reached 93.1 percent of GDP while exports were 77.9 percent. Trade deficits were financed by capital account surpluses, especially FDI. FDI grew from a negligible level in 1986 to 7.7 percent of GDP by 1993. It stagnated at 6.1 percent in 1998 and fell thereafter to less than 4 percent of GDP from 2002, before starting to recover after 2004, and exploding with WTO accession in 2007.

Changes in trade, growth and foreign investment in Vietnam were impacted not only by the globalisation crises, but also by the evolving policy environment - including trade agreements and WTO accession. In addition, external events in international markets mattered to the important exports from Vietnam (e.g., commodities - crude oil and rice - and labor intensive manufactured goods). While Figures 1 and 2 highlighted the Asian financial crisis, beginning in late 1997, and the global financial crisis of 2008, effects of other events are apparent in those graphs. Changes in 2007 as Vietnam joined the WTO and a commodity boom was unfolding were equally dramatic. Moreover, while recession began in the US in December 2007, it only spread later to other economies, and worsened around September, 2008 - if one dates the beginning of international financial crisis with the failure of Lehman Brothers. Vietnam was benefitting from the commodity boom and increased crude oil and rice prices during the first half of 2008, but had banned rice exports for a period as part of efforts to contain domestic inflation. Thus, 2008 includes both a period of rising inflation, growth and exports and a subsequent period of recession and declining trade. In world markets, trade collapsed in the last quarter of 2008 and first quarter of 2009, and Vietnam faced these impacts on its markets - if they were muted relative to other developing countries. Annual data mask somewhat short-term effects, but show the slowing of GDP and trade growth rates in 2008, and declines in both imports and exports for 2009. These events, including the mixed events in 2008, are noted in the timeline of Table 1. 
The longer period of sustained growth can also be characterized as one of increasing investment as a share of GDP. In 1995 investment was 15 percent of GDP, and that share reached 29 percent in 1998. After stalling briefly, investment rose again to 43 percent of GDP in 2007, and then fell to 38 percent by 2009. While these high investment rates contributed to rapid economic growth, Vietnamese (e.g., Doanh, 2009; MOLISA, 2009) and international observers (e.g., IMF, 2010a; Riedel, 2009) have raised the concern that aggregate incremental capital output ratios seem very high, and that growth is based on capital accumulation rather than on technical innovation. Declines in investment around the two globalization crises were smaller than in either exports or imports, and more in line with the small changes in observed GDP growth rates. But the beginning of WTO accession was accompanied by an increase in investment not fully sustained in the subsequent financial crisis. As in the earlier Asian crisis, slowing foreign investment was replaced by greater domestic investment. The policy choices to counteract recessionary forces emphasised sustained growth.

\section{Economic Performance Around Two Crises}

In this section, we focus on how real economic outcomes fared around the two recent globalization crises. Specifically, we examine GDP growth, trade, investment, employment and poverty before, during and after each crisis. We expect effects of the Asian crisis to start showing up in 1998, and effects of the great recession, financial crisis and trade collapse may not fully appear in annual data until 2009.

\subsection{GDP and its components}

Share weighted contributions to GDP growth are reported in Table 2 to illustrate the importance of trade, investment, the domestic economy and the state to economic output as proxied by contributions to GDP growth. Annual growth rates are averaged over several key periods in an attempt to capture pre- and post-crisis adjustments.

Just before the Asian crisis, in 1995-1997, GDP grew at 9.0 percent per year. It fell to 5.3 percent in 1998-1999 - the first in-crisis outcome. From 2000 to 2006 GDP growth averaged 7.5 percent, and then it peaked at the time of WTO accession at 8.5 percent. In 2009 growth had fallen again to 5.3 percent. Table 2 breaks down contributions to this growth by final demand component, by sectoral activity, and by sectoral ownership.

Contributions to GDP growth based on sectoral ownership show the rising importance of the private sector in Vietnam. A longer term policy goal has been restructuring the economy to be less dependent on SOEs and to increase the role of the private domestic sector. Private sector growth was lower than for state-owned firms before the Asian crisis, and increased significantly between the two crises. Moreover, it held up much better under both crises. Accordingly, since 2006 the contribution of the private sector has been more than double the contribution to growth of the state-owned 
Table 2. Share weighted contributions to Vietnamese GDP growth

\begin{tabular}{|c|c|c|c|c|c|c|}
\hline & & Asian Crisis & & WTO & Great Recession & \\
\hline & 1995-1997 & 1998-1999 & 2000-2006 & 2007 & 2008 & 2009 \\
\hline GDP growth & $9.0 \%$ & $5.3 \%$ & $7.5 \%$ & $8.5 \%$ & $6.3 \%$ & $5.3 \%$ \\
\hline \multicolumn{7}{|c|}{ Final Demand components } \\
\hline Consumption & $5.6 \%$ & $2.1 \%$ & $4.1 \%$ & $6.9 \%$ & $6.9 \%$ & $2.6 \%$ \\
\hline Investment & $3.4 \%$ & $1.2 \%$ & $3.9 \%$ & $10.0 \%$ & $-0.9 \%$ & $0.4 \%$ \\
\hline Govt Spend & $0.7 \%$ & $-0.3 \%$ & $0.4 \%$ & $0.5 \%$ & $0.5 \%$ & $0.5 \%$ \\
\hline Exports & $6.5 \%$ & $5.9 \%$ & $8.1 \%$ & $9.8 \%$ & $5.9 \%$ & $-6.0 \%$ \\
\hline Imports & $-6.9 \%$ & $-3.6 \%$ & $-8.7 \%$ & $-22.4 \%$ & $-6.3 \%$ & $10.3 \%$ \\
\hline Trade & $-0.4 \%$ & $2.4 \%$ & $-0.6 \%$ & $-12.6 \%$ & $-0.3 \%$ & $4.3 \%$ \\
\hline \multicolumn{7}{|c|}{ By Sectoral ownership } \\
\hline State owned & $4.1 \%$ & $1.6 \%$ & $2.8 \%$ & $2.1 \%$ & $1.5 \%$ & $1.4 \%$ \\
\hline Private & $3.6 \%$ & $2.0 \%$ & $3.2 \%$ & $4.3 \%$ & $3.4 \%$ & $3.0 \%$ \\
\hline Foreign Invested & $1.4 \%$ & $2.0 \%$ & $1.6 \%$ & $2.3 \%$ & $1.4 \%$ & $0.9 \%$ \\
\hline \multicolumn{7}{|c|}{ By Sectoral Activity (Selected sectors) } \\
\hline Agriculture & $1.0 \%$ & $1.0 \%$ & $0.7 \%$ & $0.4 \%$ & $0.8 \%$ & $0.2 \%$ \\
\hline $\begin{array}{c}\text { Natural Resources } \\
\text { \& Energy }\end{array}$ & $1.2 \%$ & $1.3 \%$ & $0.8 \%$ & $0.1 \%$ & $-0.1 \%$ & $1.1 \%$ \\
\hline Manufacturing & $2.1 \%$ & $1.6 \%$ & $2.4 \%$ & $2.6 \%$ & $2.0 \%$ & $0.6 \%$ \\
\hline Construction & $0.9 \%$ & $0.1 \%$ & $0.6 \%$ & $0.8 \%$ & $0.0 \%$ & $0.8 \%$ \\
\hline $\begin{array}{l}\text { Wholesale and } \\
\text { Retail Trade }\end{array}$ & $1.5 \%$ & $0.5 \%$ & $1.0 \%$ & $1.2 \%$ & $1.0 \%$ & $1.1 \%$ \\
\hline
\end{tabular}

Source: Computed using data from GSO online database (2011).

sector. The foreign invested sector has contributed beyond its small size due to its rapid growth, but has fallen back after each crisis, with a lag. The decline in FDI only resulted in a smaller contribution from the foreign invested sector in 2000, well after the Asian crisis, and fell more rapidly in the recent crisis from its 2007 peak. In the recent crisis both the state-owned and foreign invested sectors reacted much more strongly in terms of economic activity than did the domestic private sector, which maintained its steady growth.

The increasingly important role of the private domestic sectors and the ongoing restructuring are also seen in longer term sectoral contributions to growth. In the short term, the manufacturing sector output fell after each crisis, and was harder hit in the second crisis. Manufacturing would be more sensitive to exports than other sectors. Construction fell to almost no contribution to growth during each crisis, but quickly recovered to pre-crisis norms. Construction is heavily influenced by overall investment. Agriculture was steady during the first crisis, but has been pushed around by international commodity price swings in the recent crisis. Its contribution was already low in 2007, and increased in 2008 due to the commodity price boom. Agriculture may be influenced by exports, but has a large domestic component. Services are probably a better gauge of the domestic economy. Services output, proxied 
here by wholesale and retail trade, dipped some in the Asian crisis but remained steady during the recent crisis.

More pronounced variations were observed in two volatile components of final demand - trade and investment. Investment contributed over 3 percent and nearly 4 percent to growth during "normal" periods and peaked to 10 percent in 2007. During the Asian crisis it fell to only 1.2 percent, and it went negative in 2008. It turned positive but remained low in 2009 at 0.4 percent. Trade was even more volatile and its components - imports and exports - also showed large changes. Rapidly rising imports contributed negatively, and strongly so, to growth, peaking at 22.4 percent in 2007. In crisis periods, import growth either slowed (Asian crisis) or went negative (2009).This led to a large (4.3 percent) positive contribution of trade to growth in 2009 , since the import decline significantly exceeded the export decline. In the Asian crisis there was no significant decline in exports, as the crisis mostly affected the ability to import, whereas in the recent crisis exports fell dramatically, showing a strongly negative impact on growth that was counteracted by the bigger drop in imports. These volatile contributors to growth merit further investigation, to which we turn below, to understand why they reacted to somewhat different degrees following these two recent globalization crises.

\subsection{Trade}

In more normal years, trade as a component of final demand is a drag on growth as imports have exceeded exports, and imports have been affected more so than exports in both crises, resulting only then in positive contributions from trade to growth. The Asian crisis differed from the recent crisis in the extent to which the trend of export growth stalled - in the latter but not the former crisis. Figure 3 shows the commodity composition of exports over these periods. There is no discernible pattern in exports around the Asian crisis in this figure, while the underlying data show that an increase in the quantity of crude oil exports helped to keep exports increasing throughout the first crisis (GSO, 2011). In the second crisis heavy industrial product plus mineral exports (including crude oil) were hardest hit, following declines in the value of crude oil in the face of constant quantity and declining prices. The end of the commodity boom in 2008 affected both agricultural and mineral exports, but the high prices of early 2008 brought a supply response in rice. It appears that crude oil accounts for much of the export decline, not manufactured goods, so any GDP decline is unlikely to be stalled export led growth.

Why imports in each crisis fell more than exports, and why imports fell so much in the second crisis, are important to understanding the trade-investment-growth linkage. Figure 4 breaks the trends in imports over this period into imports of consumer goods, intermediates and capital goods, based on GSO (2011) classifications. Consumer goods were the one category to fall in the Asian crisis, from 10.1 percent to 8.5 percent of imports. Consumer goods imports stayed at this relatively small share, remaining 


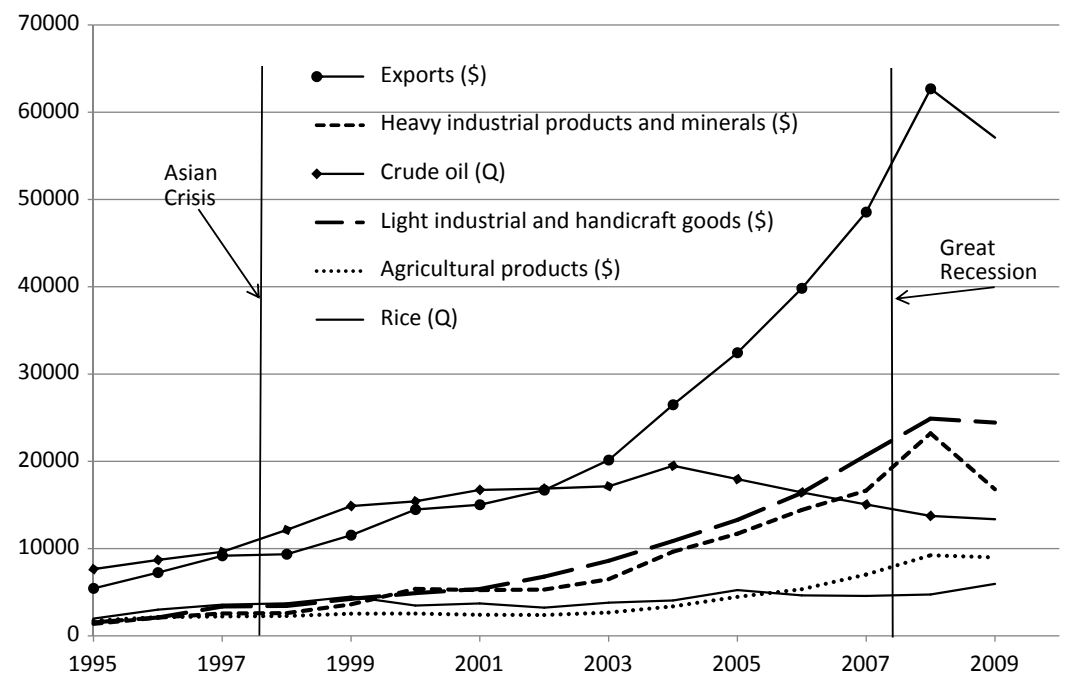

Figure 3. Commodity and manufacturing exports, 1995-2009

Note: Units of measure are US\$ millions except for rice and crude oil, which are in thousand tons.

Source: GSO online database (2011).

below 8 percent until 2009. Large declines in both intermediates and capital goods are evident in 2009. These highlight the fact that Vietnam's large share of trade in GDP is accounted for in large part by the extent to which intermediate imports are re-exported. It also shows the need to import capital goods, and that those imports are sensitive to both FDI and overall investment trends. The surge in imports in 2007 and 2008,

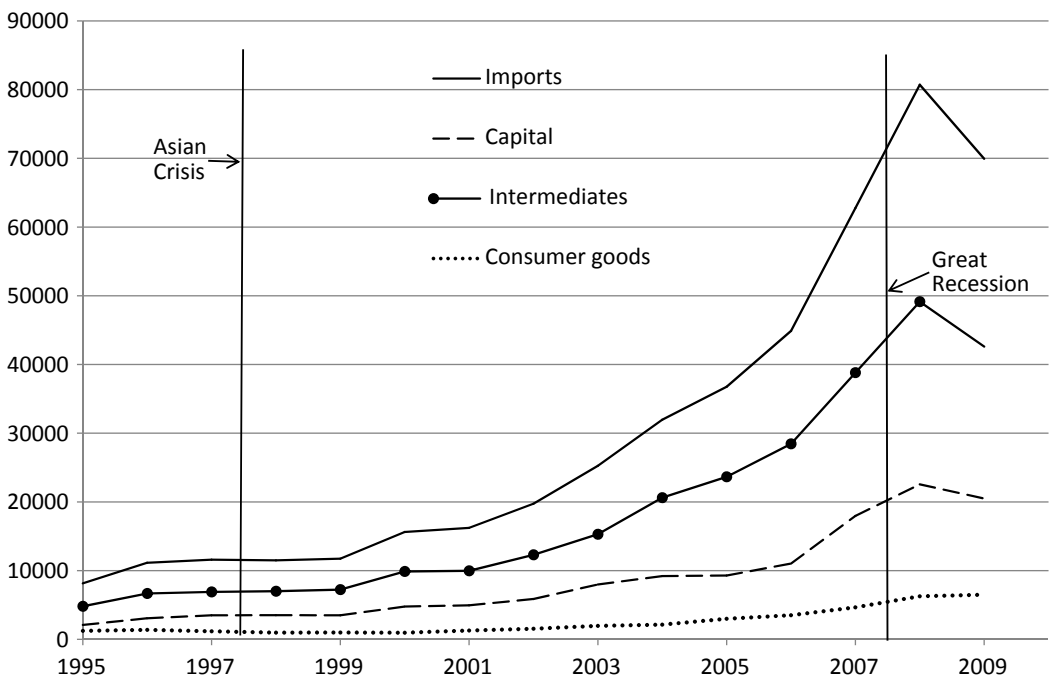

Figure 4. Imports of intermediates, capital and consumer goods, 1995-2009 Note: Units of measure are US\$ millions.

Source: GSO online database (2011). 
following WTO accession, are also led by steep increases in both intermediate and capital goods imports. The share of capital goods in imports rose from 24.5 percent in 2006 to 28 percent in 2007 and 2008, following the investment and FDI surge that accompanied WTO accession. Thus, the export-intermediate import link makes the Vietnamese sector appear somewhat like a dualistic economy, while imports are also closely tied to investment, whether it is going to the foreign invested, state-owned or private sectors.

\subsection{Investment}

Vietnam reports one investment series consistent with international accounting standards (hereafter referred to as (I) or (I in GDP)), but all other investment data (and breakdowns) are based on a larger investment level that includes various social development investments that are not part of gross capital formation. ${ }^{3}$ As noted earlier, investment (by either measure) has increased dramatically and steadily as a share of GDP. GSO reported investment has continued to exceed I in GDP, and while growth in I in GDP slowed in 2008, the overall Vietnamese defined investment did not. Moreover, I in GDP is available for 2010 and shows a further, large increase, putting it back on trend.

Moreover, in recent years investment into the domestic private sector has increased substantially. Figure 5 shows how investment and its breakdown by ownership have changed over periods around each crisis. The increase in domestic private sector investment is pronounced beginning in 2003, large in 2007 when both FDI and domestic credit surged, and resuming steady growth for 2008 and 2009. Investment in state-owned enterprises grew steadily from 1995 until 2008, and increased substantially in 2009. The one component showing negative effects of the two crises is investment in foreign-invested firms. FDI fell somewhat following the Asian crisis and was slow to resume its former growth. FDI then surged in 2007 and 2008, but again leveled off after the recent crisis. Any slowing in overall investment growth is largely attributable to FDI changes, and Vietnam appears to have stimulated investment, particularly in state-owned enterprises with a lag after each crisis to restore growth.

Figure 6 explores in more depth the changes from trends in foreign investment around both the two globalisation crises and around WTO accession in 2007. IMF (2010a) balance of payments data in that figure report a qualitatively similar but slightly smaller level of FDI than GSO (2011). GSO (2011) reports both implementations of FDI projects and registrations of intent to invest by foreign firms. The figure shows registered intent to invest has been on average about 2.5 times the actual investment. That increased even more before the Asian crisis and especially so before the recent crisis. In 2008 registered FDI was more than seven times implemented FDI.

\footnotetext{
${ }^{3}$ Table 3 shows the discrepancy between I in GDP and investment as reported by GSO (2011). Why this discrepancy is found was explained to us in a personal communication from PL Huong, Central Institute for Economic Management, Hanoi, Vietnam.
} 


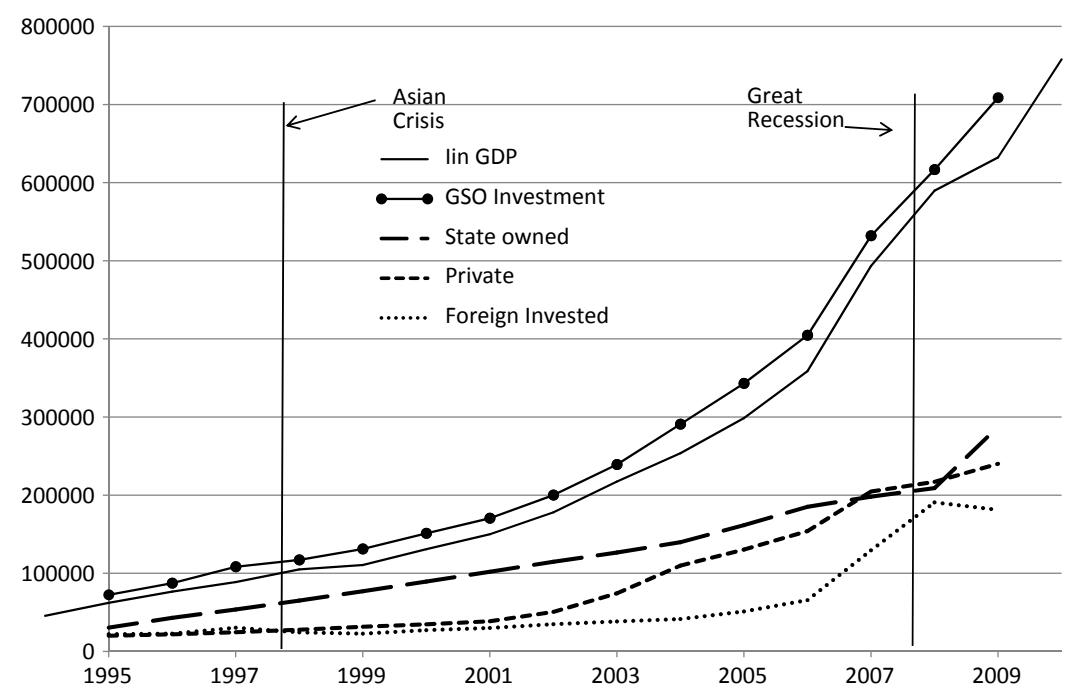

Figure 5. Vietnamese investment by sectoral ownership, 1995-2009

Note: Units of measure are billion Vietnamese dong.

Source: GSO Online database (2011).

Each time the declines in registrations were several fold the declines in actual, implemented investment. Other forms of foreign investment (other than FDI) were insignificant until 2002 and were comparable to the IMF data on FDI until 2007. There was a surge in portfolio investment in 2007 that did not continue in 2008, including foreign investment into the Vietnamese stock market. A recovery in non-FDI foreign investment in 2009 is explained in part by foreign financing of the government deficit.

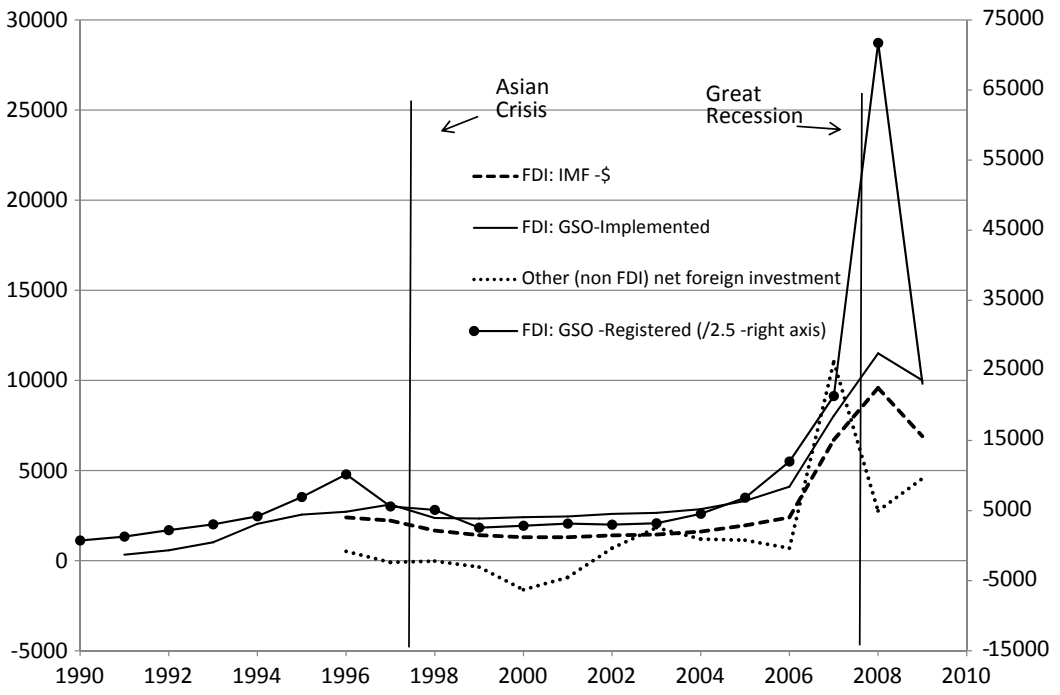

Figure 6. Foreign direct investment (FDI) into Vietnam, in million US\$

Source: GSO Online database (2011) and IMF (2010a). 
This information shows steady investment, except FDI, in the Asian crisis, and an effort in the recent crisis by the government to make up for shortfalls in foreign investment brought about by that crisis. Critical issues are whether the macroeconomic policy responses have made for a less attractive environment for resumed foreign investment, and whether the increasing role of the domestic private sector can make up for less FDI in the future.

\subsection{Unemployment and poverty}

Real economic outcomes following each crisis were less volatile than changes in trade or even investment. As noted earlier, slowing of GDP growth was less in Vietnam than in other Asian economies, and certainly less than one would expect from an "export led" economy facing such large changes in trade, particularly over the recent crisis. This stability in GDP growth also shows up in data on employment, hence unemployment, and in poverty reduction.

The Asian crisis had a bigger effect on unemployment than the recent crisis. In 1996 and 1997 unemployment was about 6 percent. It rose to 6.8 percent in 1998 and 1999, and subsequently fell from that level to 4.64 percent in 2007. Unemployment stayed at essentially that same level in 2008 and actually fell slightly to 4.60 percent in 2009 . Hence, there was a slight increase in unemployment in the Asian crisis, and no discernible effect in the recent crisis. Some observers, including both Vietnamese critics and the World Bank (MOLISA, 2009; Doanh, 2009; Mishra and Dinh, 2010) find anecdotal evidence of emerging unemployment in export manufacturing, foreign invested enterprises, and export oriented handicraft villages, as would be expected from the lost exports. But recent labor surveys seem to suggest lost jobs due to the fall in exports were largely made up in the domestic informal sector (Chí et al., 2010). They also note that the relationship between GDP growth and employment has always been weak in Vietnam. Prior to both crises, when GDP was growing faster than 6 percent per year, employment growth remained below 2 percent per year (MOLISA, 2009). While employment growth has been much slower than GDP growth, unemployment has fallen nevertheless. ${ }^{4}$ MOLISA (2009) credits government policy responses with minimizing the effects of the recent external crisis on overall employment.

Another dimension of real economic welfare is poverty reduction. The longer term view is that economic development in Vietnam has been quite successful in reducing poverty. The World Bank's (2011) indicator of extreme poverty, the headcount index of population earning less than US\$1.25 per day, was 64 percent in $1993 .{ }^{5}$ By 1998 ,

\footnotetext{
${ }^{4}$ Underemployment in rural areas may also have been exacerbated by the recent crisis, but it is difficult to find data to determine the extent of this. MOLISA (2009) notes that there were Vietnamese working overseas who were forced to return home, and who returned to rural areas to seek work, contributing to widespread underemployment.

${ }^{5}$ Poverty indicators are only available for years in which the Household Living Standards Survey (VHLSS) was conducted. That is done more frequently now than before 2000, but data after the recent crisis remain preliminary.
} 
during the Asian crisis, that had fallen to 50 percent, by 2002 it was 40 percent, and by 2006 it stood at 21 percent. According to the World Bank office in Hanoi "The poverty head count fell by around 1 percentage point each year between 2006 and 2008, as compared to 2-3 percentage points per year in earlier periods" (Dinh and Rama, 2009:4). Hence, it appears poverty continued to fall even during the recent crisis. A slowdown in its rate of decline is to be expected as the headcount index decreases. Of course, Vietnam is like other developing countries in that poverty is much greater in rural areas, and agriculture was less likely to be affected by external crisis than urban activities and especially manufacturing. But the data do suggest the policies pursued in Vietnam, to which we now turn, maintained growth and also protected employment and the poor.

\section{Policy Responses to Crises}

Information is more extensive on Vietnamese monetary and fiscal policy following the recent crisis than the Asian crisis, since the government appears to have more actively responded to what amounted to a more severe crisis. The 1999 IMF country report (IMF, 1999), based on consultations with the Vietnamese government, emphasized structural issues related to state involvement in the economy, which they believed were more important than the Asian crisis to the Vietnamese economy. That report described cautious monetary and fiscal policy and stable exchange rates as the stance of the government. They saw the most significant change being the slowdown in FDI into Vietnam, but were already concerned with the economy's ability to absorb that FDI. Money supply growth in 1998 was evident in credit to SOEs and reduced interest rates, however. A subsequent look at data is not entirely consistent with the story told there as the exchange rate did depreciate and exports did not appear to be as weak as the report suggests in revised data. But government spending and investment in SOEs remained steady over that period.

More is written now about the "stop-go" macroeconomic policies in response to not only the 2008 crisis, but also WTO accession and the commodity boom that had brought surges in foreign investment and inflation (IMF, 2010a; Riedel, 2009; Doanh, 2009; Mishra and Dinh, 2010). The Vietnamese initially reacted strongly to tame that inflation, but quickly reversed course as events in 2008 and 2009 unfolded. Both monetary and fiscal policies were used to promote growth over stability, according to that literature. Another way of characterizing the tradeoffs is between real economic outcomes - growth, employment and poverty reduction - and financial outcomes — inflation and deficits.

\subsection{Fiscal policy}

Government spending on goods and services as a component (G) of GDP has been a steady but small contributor to growth. In the Asian crisis, spending fell, whereas in the 


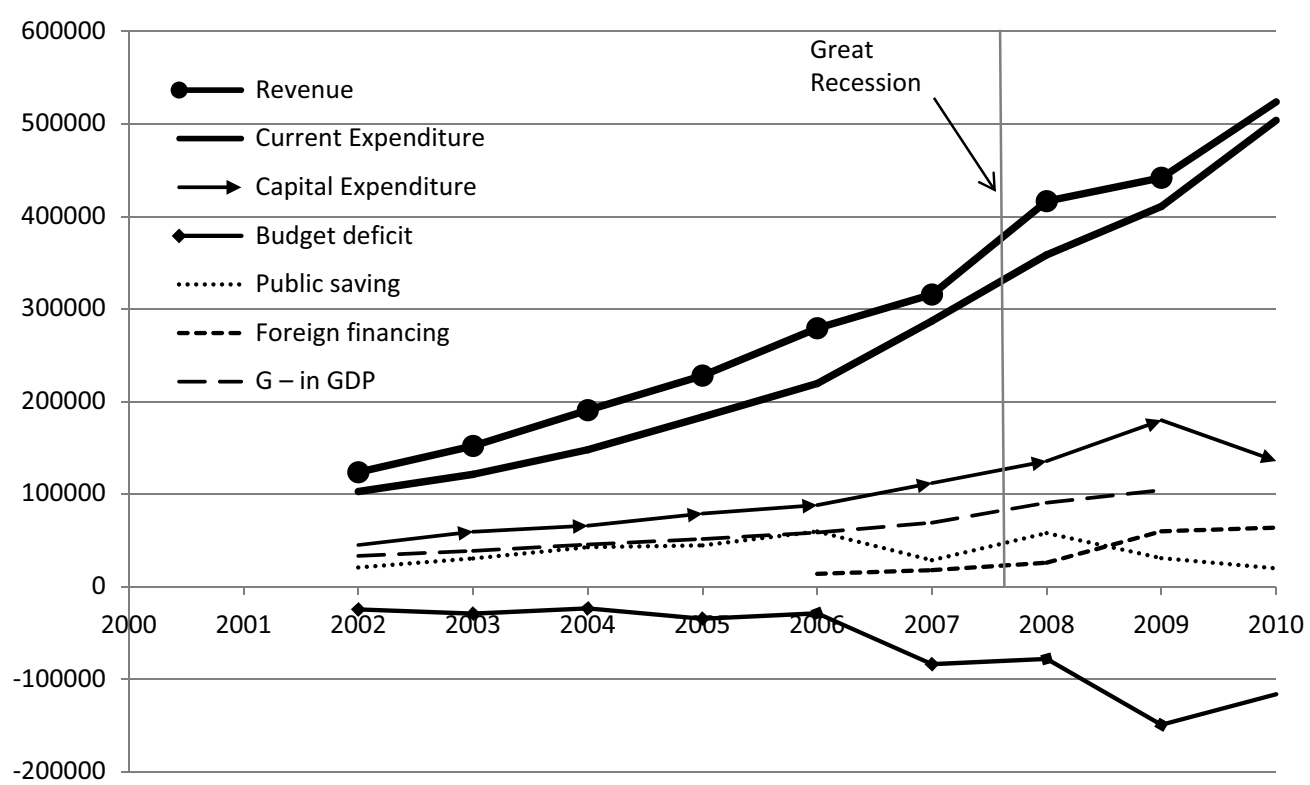

Figure 7. Vietnamese government budget balance, 2000-2010

Note: Units of measure are billion Vietnamese dong.

Source: GSO online database (2011) and IMF (2010a).

recent crisis spending and its contribution to GDP growth remained constant at 0.5 percent (see Table 2). Fiscal policy involves more than G in GDP, however, including tax policy and in the case of Vietnam public investment and investment through SOEs. Data on Vietnamese government budgetary operations remains contentious, in part based on how on-lending to SOEs is treated (IMF, 2010a). These are formally labeled "off-budget expenses" in GSO (2011) accounts. The IMF does not report Vietnamese government budgetary data in its international database (IMF, 2011) and data available from statistical appendices to IMF country reports (IMF, 2003) is inconsistent both in treatment of off-budget expenses and in estimates of capital versus current expenditures as well as net budget deficits realised. Widening budget deficits are evident around both globalization crises, but appear to increase well before the international crises take hold. Before the recent crisis, WTO accession and its accompanying resource inflows brought optimistic budgetary decisions that made budget deficits persist during and after the crisis. Had the government backed off on those decisions during the great recession, negative impacts on GDP likely would have been larger.

Around the Asian crisis, revenue and various expenditure components continued to rise, and deficits increased in 1998 and beyond. Foreign financing of budget deficits also increased, but the policy discussion was more about investment in foreign invested and state owned enterprises than about fiscal stimulus to counteract recession (IMF, 1999). The recent crisis brought more evident, faster fiscal responses, even if the deficit had begun to increase earlier. Numerous fiscal stimulus measures were pursued starting in December 2008 including measures to support small and medium 
enterprises with tax reductions and interest rate subsidies; to stimulate private consumption with VAT and income tax cuts; to accelerate public investment both on and off-budget; and to strengthen safety nets (IMF, 2010a).

A consequence of fiscal stimulus has been a substantially increased government budget deficit. Figure 7 shows revenue, current and capital expenditures, and the resulting budget deficit for Vietnam from 2000 to 2010, when GSO (2011) data is available. Vietnam has consistently maintained current expenditure below revenue, leading to apparent "public saving." It has also invested in the economy through increasing capital expenditures that jumped in 2009 and are expected to fall back somewhat in 2010 as stimulus ends. This public investment always exceeded "public saving," yielding a deficit to be financed by either private or foreign savings. The budget deficit had already increased in 2007. High crude oil prices and so greater revenue allowed the deficit to stay constant in 2008 , and greater foreign financing has been used to maintain the large deficits incurred in 2009 and 2010. G in GDP and current expenditure grew following past trajectories during this period. With a lag this policy enabled replacement of foreign investment by private and state enterprise investment. The result was fiscal policy fostering sustained (if a bit slower) economic growth at the cost of a budget deficit that at its peak in 2009 equaled 9 percent of GDP. It had been only 2.9 percent of GDP in 2006, and fell back to 5.9 percent of GDP in 2010.

\subsection{Monetary policy, inflation and the exchange rate}

Monetary stimulus was also applied in 2009. The State Bank of Vietnam cut interest rates, reduced reserve requirements, and injected liquidity through open market operations (IMF, 2010a). The state set interest rates remain contentious as Vietnam balances a desire to maintain rapid growth and keep credit available to domestic industries while inflation remains high and pressure for the currency to depreciate further has persisted.

The IMF (2010a:38) characterises Vietnamese monetary policy as "a combination of exchange rate targeting and monetary targeting regimes, made possible by existing capital controls." This regime looks from the outside a bit like a fixed exchange rate regime over normal periods, until crises set in, with balance of payments effects spilling over onto domestic money supply. The exchange rate remained steady from 2002 through 2007, even as the current account deficit soared. Surplus on the financial account exceeded deficit on the current account in 2007 (and before) as international reserves accumulated to accommodate inflows of foreign investment. Riedel (2009) notes that accumulation of international reserves, particularly in 2007 and 2008, helped to expand domestic credit and fuel inflation. During both crises, however, the dong was allowed to depreciate faster than inflation would require, and so the real exchange rate also depreciated. In 2008, this followed a huge real exchange rate appreciation led by a spike in inflation and an effectively fixed nominal exchange rate. Figure 8 shows the evolution of the real and nominal exchange rates as well as indicators of inflation. 


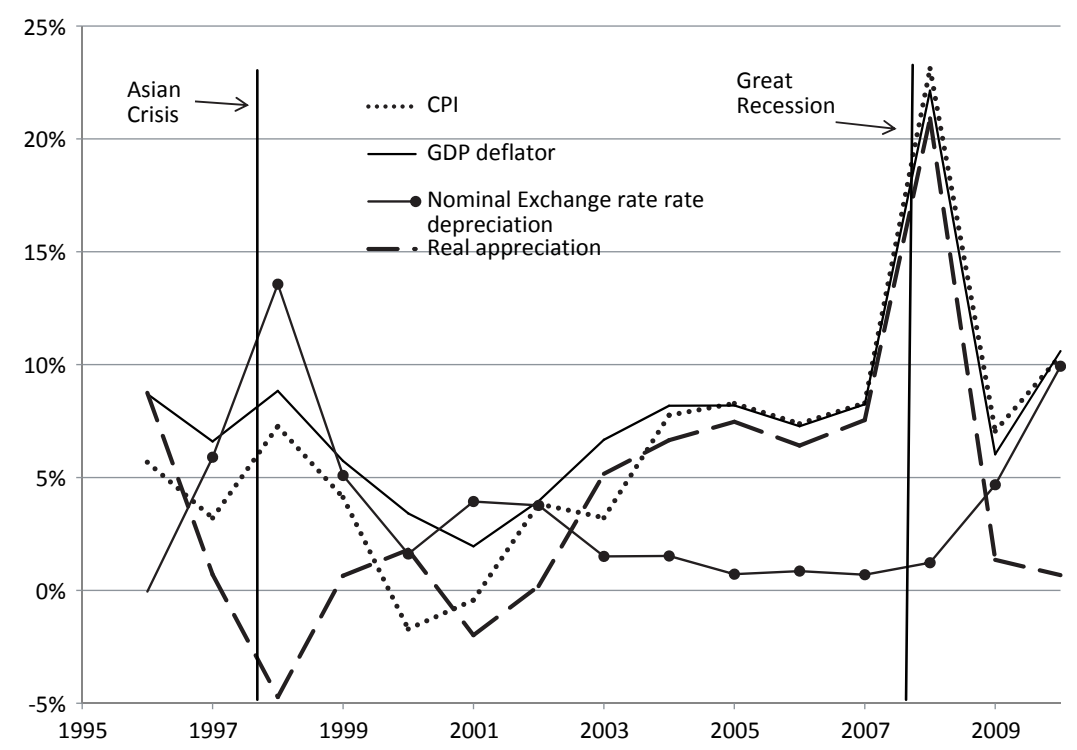

Figure 8. Inflation and the exchange rate, percent change from previous year, 1996-2010 Source: GSO online database (2011).

Each globalization crisis featured real exchange rate depreciation during the crisis, as the nominal exchange rate was allowed to depreciate faster than the rate of inflation. Following the Asian crisis nominal depreciation was stronger, and inflation did not follow immediately. The stable exchange rate period leading up to WTO accession was characterized by a relatively fixed exchange rate and rising inflation, enabled by renewed foreign capital inflows. The nominal exchange rate depreciated faster in 2010 than 2009, allowing resumption of exports. But the policy regime and recession may have brought the spike in inflation under control in 2009, only to see inflation surging again in 2010. Earlier, inflows of foreign capital were driven by foreign investment interest, and the currency remained stronger, while recent inflows to finance public debt come with a weaker currency and this depreciation probably also fuels domestic inflation. These were exacerbated by changes in foreign currency holdings of Vietnamese residents, who shifted from domestic assets to gold and dollars, even as the current account remained stable. The challenges to the central bank in managing monetary policy in this environment are formidable, yet it succeeded in reducing the peak inflation of 23 percent in 2007, and inflation now is only a few percent above rates realized in the run-up to WTO accession.

\section{Financing Deficits}

Typically external shocks as seen in the recent globalization crises would impact macroeconomic balances and especially the twin deficits - the current account deficit and the government budget deficit. In the case of Vietnam, external shocks were 


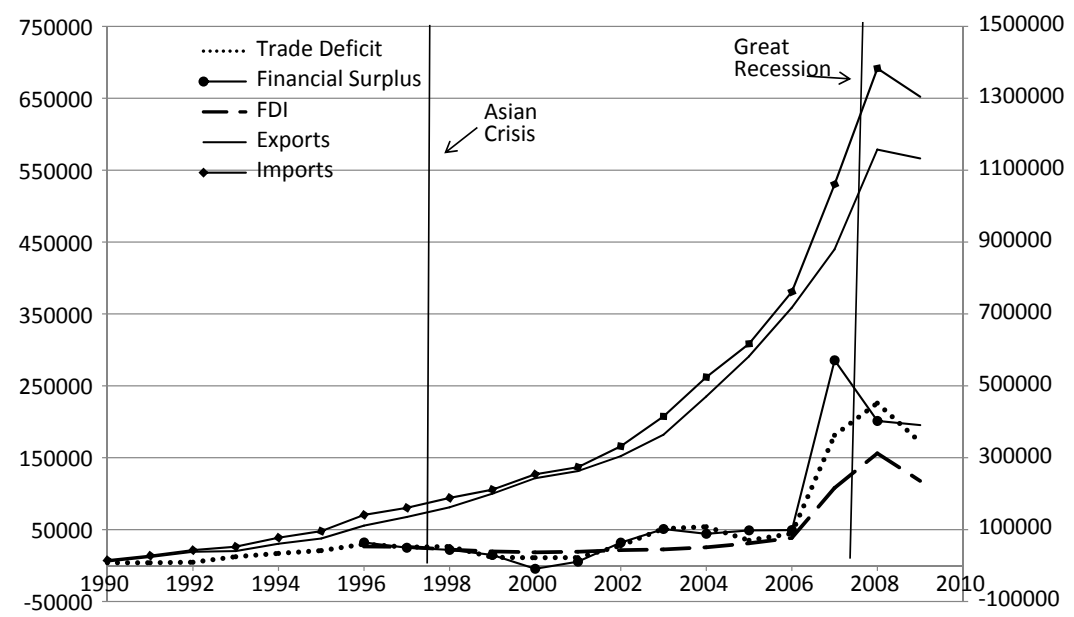

Figure 9. Trade and international financial balances, 1990-2009

Note: Units of measure are billion Vietnamese dong. Exports and imports use right axis.

Source: GSO online database (2011) and IMF (2011).

already impacting the economy prior to the official inception of the crisis. The government budget deficit was explored in the section examining fiscal policy above. It was seen that this deficit was rising before each crisis began, and was influenced by efforts to maintain or expand investment in the face of varying foreign capital inflows. The current account deficit, which is matched by a financial account surplus can be either a positive or negative outcome, depending on what is driving that deficit. If falling exports are contributing to a trade deficit, financial inflows may allow sustained imports. Foreign financing may also be required to prevent government budget deficits from crowding out investment. But foreign financing may also be coming to an attractive investment opportunity, as was the case in Vietnam both in the mid 1990s and following WTO accession. The basis for a current account deficit then may differ before and after a crisis begins.

Figure 9 examines the evolution of trade, the current account and the financial account in Vietnam over periods around both recent globalization crises. The figure shows the explosion of trade in Vietnam, with imports exceeding exports and there being a persistent current account deficit. The trade deficit was rising over the 1990s until 1997, and it fell until after 2000, to a third of its 1996 peak. As in the later crisis, imports shrank more than exports, and capital flows likely drove trade balance. FDI declined after the Asian crisis, but not immediately and not as drastically as the financial surplus. There was a large increase in international liabilities of the banking sector that counteracted the inflow of FDI of over US\$2 billion in 2000, following a decline in reserves of nearly US $\$ 1$ billion the year before. This may have been motivated by the substantial real depreciation of the dong. These currency movements diminished the savings available to the domestic economy, below the influx of FDI. Not only FDI inflows, but also other components of foreign savings influenced 
the savings-investment balance which the government sought to maintain to foster continued growth.

Events in foreign capital flows during the latter crisis were even more dramatic, and followed the surge in both FDI and other forms of foreign investment into Vietnam as a consequence of WTO accession. Registered intentions to invest in Vietnam by foreign investors increased nearly seven-fold from 2006 to 2008, and implemented FDI rose nearly 3-fold, while IMF's measure of FDI nearly quadrupled. While FDI was about two thirds of the increase in financial surplus, other foreign capital sources, especially portfolio investment in 2008 also surged and accounted for the remaining third of the increase. This came following a strong prior trend of increasing foreign capital inflows. While the current account deficit and trade balance greatly expanded, that was less than the financial account surplus, and international reserves also increased, by more than the current account deficit.

This picture then changed dramatically as the financial crisis unfolded in 2008 and 2009. Exports fell for the first time since "Doi Moi" but imports fell more and the current account narrowed. FDI peaked in 2008 and returned to its 2007 level in 2009, but this still represents a doubling of annual FDI inflows realised through 2006. Similar and larger changes are observed for the financial account surplus, and reserves did not continue to accumulate in 2008 and 2009. Reserves accumulation led to a stable exchange rate in 2007 in spite of the larger trade deficit, while the currency began to depreciate in spite of a shrinking trade balance as a result of diminished foreign capital inflows. Foreign capital inflows in 2009 fell less than the trade deficit or FDI as the government sought foreign financing to support the rising budget deficit.

Table 3 explores the implications for the savings-investment balance of these changes in foreign investment and government savings and investment around the recent crisis, where consistent data is available. Values are reported in real 2008 dong to facilitate comparisons. Increasing investment has been one of the keys to rapid economic growth in Vietnam. WTO accession brought a 20 percent surge in investment to raise the growth rate to 8.5 percent. This was due not only to an increase in investment in foreign invested firms, but also increases in the private domestic sector, with investment in SOEs flattening out then. Investment stalled with the great recession in 2008 and 2009, and resumed growth in 2010. This was seen in both FDI and private investment, while investment in SOEs increased to partially compensate the decline. By its own measure of investment, that includes social development capital, Vietnam had already moved to increase overall investment in 2009. State capital expenditure was up in 2009, and fell in 2010 as the private investment sources recovered and budget pressures set in. The private domestic sector was already recovering in 2009 as well. Thus, Vietnam quickly restored high levels of investment in the face of the foreign finance shock to sustain as much as possible economic growth.

The government budget has always included significant capital expenditures as well as off-lending to SOEs. While the government runs a deficit, revenue exceeds current expenditures, so public saving covers some of state capital expenditures. In 2008, 
Table 3. Savings-investment balance

\begin{tabular}{lrrrrrr}
\hline & \multicolumn{7}{c}{ WTO } & Great Recession & \\
\hline & $2000-2005$ & 2006 & 2007 & 2008 & 2009 & 2010 \\
\hline Investment (1 in GDP) & 345 & 478 & 607 & 590 & 591 & 641 \\
Investment (GSO) & 391 & 540 & 655 & 617 & 662 & \\
$\quad$ State capital expenditure & 89 & 118 & 138 & 136 & 168 & 115 \\
"Private" I by ownership & 114 & 129 & 106 & 73 & 100 & \\
$\quad$ SOEs & 126 & 205 & 252 & 217 & 224 & \\
$\quad$ Private & 62 & 87 & 159 & 191 & 169 & \\
$\quad$ Foreign invested & 48 & 80 & 35 & 58 & 29 & 17 \\
I $=$ Savings & 42 & 38 & 103 & 78 & 139 & 98 \\
$\quad$ Public saving & 54 & 66 & 352 & 201 & 183 & 192 \\
$\quad$ Govt budget deficit & & 19 & 22 & 26 & 56 & 54 \\
$\quad$ Financial acct surplus & & & & & & \\
$\quad$ Foreign public finance & 290 & 394 & 268 & 357 & 451 & \\
Private saving & 243 & 333 & 220 & 330 & 379 & 432 \\
based on I (GDP) & & & & & & \\
\hline
\end{tabular}

Note: Units of measure are trillion real (2008) Vietnamese dong.

Sources: Computed using data from GSO, Online database (2011) and IMF (2010a).

revenue and so public saving had increased due to high crude oil prices. It had fallen in 2007 as current expenditure and the deficit increased, and repeated that outcome in 2009 as fiscal measures stimulated the economy. In 2010 public saving was very low, but the budget deficit was less as stimulus measures had ended and the government was addressing budget pressure. Nevertheless, to ensure that budget deficit would not crowd out private investment the government sought foreign financing to an extent not seen before - at double the level prior to the crisis.

Variations in the financial account surplus have been a primary external shock to the Vietnamese economy. Foreign financial inflows, especially private inflows, surged to six times the combined earlier level just prior to the crisis. They fell back as the crisis ensued, but remained at elevated levels. This brought big swings in our estimated domestic private savings, equal to total investment plus the government budget deficit less foreign financing. Requirements for domestic savings fell by nearly one-third in 2007 , only to return to nearly the 2006 level in 2008. Big increases in domestic savings were needed in 2009 and 2010 to permit the resumption of investment and counteract the crisis, to levels higher than the peak in 2006. These demands for credit from the domestic market have helped to fuel inflationary pressures that had already begun with the final demand shock that accompanied WTO accession. These fluctuations slowed somewhat investment in the private domestic sector, which resumed growth in 2009 after falling in 2008. Maintaining growth in the private sector, fostered by monetary and fiscal stimulus, has undoubtedly helped Vietnam weather the storm of external shocks brought about by the recent globalization crisis. 


\section{Concluding Remarks}

Vietnam is an example of a country that has responded strongly to counteract external shocks. It reacted more quickly to the stronger shock of the most recent crisis, which was also more severe. Its success in coping with these crises contradicts its characterisation as an example of export led growth and highlights the role of the state, particularly in maintaining and influencing investment. Declines in investment around globalization crises were smaller than in either exports or imports, and more in line with the small changes in observed GDP growth rates. While there was a significant trade shock following the collapse in global trade in late 2008, reducing exports 7.7 percent in the recent crisis, impacts on foreign financial flows and particularly foreign investment appear to be more significant in each case.

On the positive side, Vietnam's policy interventions have sustained economic growth rates at nearly pre-crisis levels. The domestic economy absorbed the shock with little evidence of changes in overall employment, and with the trend of declining poverty continuing. On the negative side, the policy interventions have brought inflation, currency depreciation, and bigger government budget deficits. The current account deficit in pre-crisis periods reflects the attractiveness of Vietnam as a destination for foreign direct investment, while it fell as imports fell more than exports initially in the recent crisis, and is now higher as Vietnam utilizes more foreign financing to cover its budget deficit.

In the Vietnamese case, the links between trade, economic growth and poverty reduction were broken. The great recession and accompanying trade collapse brought reductions in export growth, but domestic stimulus measures and private domestic sector adjustments led to only small declines in economic growth rates. Because the link between trade and poverty worked through economic growth, and domestic policies were directed at poverty alleviation, Vietnam continued to reduce poverty in spite of this negative trade shock.

While real side domestic effects are quite positive, the foreign investment community is much less favourable on the performance of the Vietnamese government. They are much concerned with the prospects for inflation, currency devaluation and deficits requiring financing (Hookway, 2010; Bland, 2011). The Bretton Woods institutions have also complained about the "stop-go" nature of Vietnamese macroeconomic policy. They are not only concerned with what they perceive as inconsistency, but also would prefer a strategy that emphasized stability over growth (IMF, 2010a; Mishra and Dinh, 2010). Some Vietnamese critics (e.g., Doanh, 2009) have also been critical of steps taken by the government. These assessments strongly reflect differing value judgments on the tradeoffs between inflation and unemployment, as well as differing views on the inefficiencies generated by the state role in the economy. They are also based on differing views on the strength of causal linkages between macroeconomic variables, especially growth and inflation. Moreover, following the Asian crisis FDI inflows were slow to recover. In the very short run in 
response to the recent crisis, the Vietnamese government made up FDI shortfalls with domestic investment, including into SOEs. But emphasis on restructuring toward the private sector has been maintained.

In the aftermath of the recent crisis and subsequent recovery in Vietnam and elsewhere in Asia, debate has focused on inflation. At 10 percent in 2010, inflation in Vietnam is only slightly higher than the 7.5 percent rate realized from 2004 to 2007 , and much lower than the 23 percent in 2008. The debate over growth versus stability, where stability translates as inflation, has intensified. The "stop-go" nature of Vietnamese policy can be seen two ways. On the one hand, government has been required to adjust to changing external shocks. On the other hand, policy targets vis-à-vis inflation versus growth have not always been entirely clear. The government has been seeking a balance under pressure from both internal and external critics that realises its growth potential. While the recent dependence on foreign financing means the Vietnamese cannot ignore these criticisms, it is clear that they have made choices they view as most beneficial to the future of the domestic economy. In our overall assessment they have been quite successful in managing severe external shocks to that end.

\section{Acknowledgements}

We are grateful to colleagues at the Central Institute of Economic Management (CIEM), Hanoi, Vietnam and to Simon McCoy for useful comments. Financial support from Danida is acknowledged as well. The usual caveats apply.

\section{References}

Abbott, P, J Bentzen and F Tarp (2009). Trade and development: Lessons from Vietnam's past trade agreements. World Development, 37(2).

Abbott, P, K Boys, PL Huong and F Tarp (2008). Trade and development in Vietnam: Exploring investment linkages. Paper presented at the Symposium on Globalization and the Rural-Urban Divide initiated by the International Agricultural Trade Research Consortium (IATRC), Seoul, June 29-July 1.

Abbott, P, C Wu and F Tarp (2010). Vietnamese trade and development: Post WTO Accession. CIEM-Danida Working Paper, Hanoi, January.

Bland, B (2011). Cautious leadership in Hanoi leaves challenges unresolved. Financial Times, January 11.

Chí, N, N Huyên, M Razafindrakoto and F Roubaud (2010). Vietnam labor market and informal economy in a time of crisis and recovery 2007-2009. Policy Brief, GSO-ISS/IRDDIAL project, GSO, IRD, World Bank and UKAid, Hanoi, December.

Dinh, V and M Rama (2009). Taking stock: An update on Vietnam's recent economic developments. World Bank, Hanoi, December.

Doanh, LD (2009). Analysis of the impacts of the global financial crisis on social and economic indicators in Vietnam. United Nations Development Programme, Hanoi.

General Statistical Office of Vietnam (GSO) (2011). Statistical data, Online Database, GSO, Hanoi. Available at http://www.gso.gov.vn/default_en.aspx?tabid=491. 
Hookway, J (2010). Vietnam battles dark side of boom. Wall Street Journal, December 15.

International Monetary Fund (IMF) (1999). Vietnam: Selected issues. IMF Country Report No. 99/55, Washington DC.

International Monetary Fund (IMF) (2003). Vietnam: Statistical appendix. IMF Country Report No. 03/382, Washington DC.

International Monetary Fund (IMF) (2010a). Vietnam: Staff report for the 2010 Article IV Consultation. IMF Country Report No. 10/281, Washington DC.

International Monetary Fund (IMF) (2010b). World economic outlook database. IMF, Washington DC, October. Available at http://www.imf.org/external/pubs/ft/weo/2010/02/ weodata/index.aspx.

International Monetary Fund (IMF) (2011). International financial statistics. IMF, Washington DC, Online database, http://www.imfstatistics.org/imf/.

Mishra, D and V Dinh (2010). Taking stock: An update on Vietnam's recent economic developments. World Bank, Hanoi, December.

Ministry of Labor, Invalids and Social Affairs (MOLISA) (2009). Vietnam labor and social trends 2009: In international integration context. MOLISA and ILO, Hanoi, Vietnam, November.

Nga, NQ (2007). Viet Nam's accession to the WTO: Implications of the negotiation outcomes. Consultant report for CIEM, Hanoi, Mimeo. Available at http://www.ciem.org.vn/home/en/ home/InfoDetail.jsp?area $=1 \&$ cat $=348 \& I D=1425$.

Niimi, Y, PV Dutta and LA Winters (2007). Trade liberalisation and poverty dynamics in Vietnam. Journal of Economic Integration, 22(4), 819-851.

Riedel, J (2009). The global economic crisis and its long-run implications for Vietnam. United Nations Development Programme, Hanoi, September.

Thanh, VT (2005). Vietnam's trade liberalization and international economic integration: Evolution, problems and challenges, ASEAN Economic Bulletin, 22(1), 75-91.

World Bank (2011). World Development Indicators. World Bank. Washington DC, Online database.

World Trade Organization (WTO) (2010). World trade developments in 2009. WTO. Geneva. Available at http://www.wto.org/english/res_e/statis_e/its2010_e/its10_world_trade_dev_e.htm. 